\title{
Odontogenic Keratocyst: Eight-Year Follow-Up After Conservative Treatment
}

\author{
Queatoquiste Odontogénico: Seguimiento de Ocho Años \\ Después del Tratamiento Conservador
}

\begin{abstract}
Daiana Cristina Pereira Santana; Juliana Jorge Garcia²; Liliane Elze Falcão Lins Kusterer; Sandra de Cássia Santana Sardinha² \& Weber Ceo Cavalcante ${ }^{2}$
\end{abstract}

SANTANA, D. C. P.; GARCIA, J. J.2; KUSTERER, L. E. F. L.; SARDINHA, S. C. S. \& CAVALCANTE, W. C. Odontogenic keratocyst: Eight-Year follow-up after conservative treatment. Int. J. Odontostomat., 15(2):520-525, 2021.

\begin{abstract}
This study aimed to describe the conservative surgical management of odontogenic keratocyst, comparing with clinical and demographic findings in the literature, based on a literature review, using the quality criteria established in the literature for clinical cases and case series. We searched for cases of keratocysts published in four databases. We selected cases of patients followed up at least one year after sugical treatment. We described the case of a patient who was asymptomatic, and the lesion was detected by routine radiographic examination. At the same surgical time, we enucleated the lesion, followed by curettage and drain installation. Currently, there are no signs of disease recurrence. We followed the CARE guidelines (Case Report Guidelines), in this report. Literature review disclosed 27 cases. Keratocyst was frequent in male-adult patients, and the mean follow-up time after surgery was $46.7 \pm 28.1$ months. The main clinical findings such as association with teeth, location, extension of lesion, and radiographic pattern corroborate the classic pattern of described cases reported by literature with a low general rate of recurrences. In conclusion, conservative treatment was successful for the clinical case described, over an eight-year follow-up. Most of the described studies did not show lesion recurrence after using the conservative surgical treatment. However, we draw attention to the importance of the long follow up period of our case.
\end{abstract}

KEY WORDS: keratocyst, odontogenic cysts, odontogenic tumor, case report.

\section{INTRODUCTION}

The fourth edition of the Head and Neck Tumors Classification published by the World Health Organization (WHO) in 2017, reclassified the odontogenic keratocyst (OKC) as "odontogenic developmental cysts". The OKC remained distinct from the orthokeratinized odontogenic cyst and maintained the histopathological criteria established in 2005 (Speight et al., 2017).

The WHO classification (2017) showed that there was insufficient evidence to support a neoplastic origin of OKC (Borghesi et al., 2018). However, its aggressive behavior, similar to odontogenic tumors, must be considered during the surgical approach. Due to its aggressive characteristics and susceptibility to recurrence, several surgical treatment modalities have been described. There is no consensus in the literature to indicate the best treatment for OKC, as well as the safest follow-up time, although studies suggest a monitoring period of more than five years (PitakArnnop et al., 2010; Hadziabdic et al., 2019).

${ }^{1}$ Departamento de Estudios de Posgrado en Odontología y Salud, Facultad de Odontología UFBA- Universidade Federal da Bahia/ FAPESB- Fundação de Amparo à Pesquisa do Estado da Bahia, Salvador, BA, Brasil.

${ }^{2}$ Departamento de Cirugía Maxilofacial y Traumatología, Facultad de Odontología UFBA- Universidade Federal da Bahia/ OSID- Obras Sociais Irmã Dulce, Salvador, BA, Brasil.

${ }^{3}$ Departamento de Medicina Preventiva y Social, Facultad de Medicina da Bahía, UFBA- Universidade Federal da Bahia, Salvador, BA, Brasil.

Received : 2020-08-29 Accepted: 2020-11-11 
We aimed to describe the conservative treatment of odontogenic keratocyst in a case followed up for eight-years. We discussed the reported case with findings from the current literature. The present case report was approved by the Ethics Review Board for Research in Humans, Faculty of Dentistry, Federal University of Bahia, Brazil, number 3.438.455.

\section{CASE REPORT}

A 14-year-old male patient, physical status ASA I, was referred by his orthodontist to the Maxillofacial Surgery clinic. The patient was asymptomatic, and the clinical examination did not show an increase in the volume of the jaws or pain on palpation.

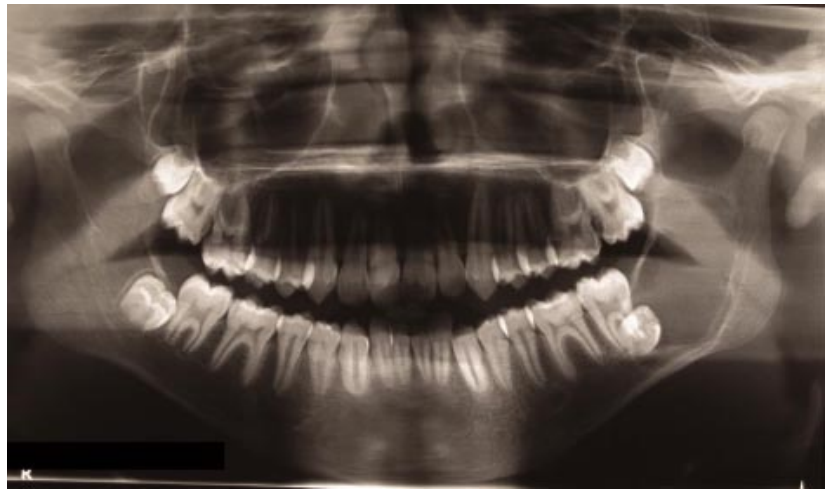

Fig. 1. Preoperative radiography, showing a unilocular lesion in the left mandibular ramus/angle.
The initial imaging exam (panoramic radiography) showed the presence of a well-defined radiolucent lesion on the left side of the mandible, affecting its angle and ramus, and an included third molar (Fig. 1). A computed tomography scan of the face revealed a large cystic lesion, involving not only the referred bone structures but also the body of the mandible and the second molar. We performed an incisional biopsy, which histopathological examination confirmed the clinical suspicion of odontogenic keratocyst.

Since the cyst was large with thinning of the mandibular cortex, presenting an imminent risk of fracture, we conducted surgical treatment under general anesthesia. We conducted the enucleation followed by delicate curettage and installation of a rigid drain (FigS. 2A, 2B and 2C). We instructed patient to perform the local irrigation with chlorhexidine digluconate $(0.12 \%)$ three times a day.

The second histopathological examination (Fig. 3) showed a cystic lesion containing a fibrous wall covered by stratified parakeratinized and atrophic epithelium, showing a flat interface with the adjacent connective tissue. These findings confirmed the histopathological analysis of the incisional biopsy.

We removed the drain after a month, and healing occurred by secondary intention. We conducted clinical and radiographic monitoring for eight years. There was evidence of new bone formation and no sign of recurrence of the lesion (Fig. 4).
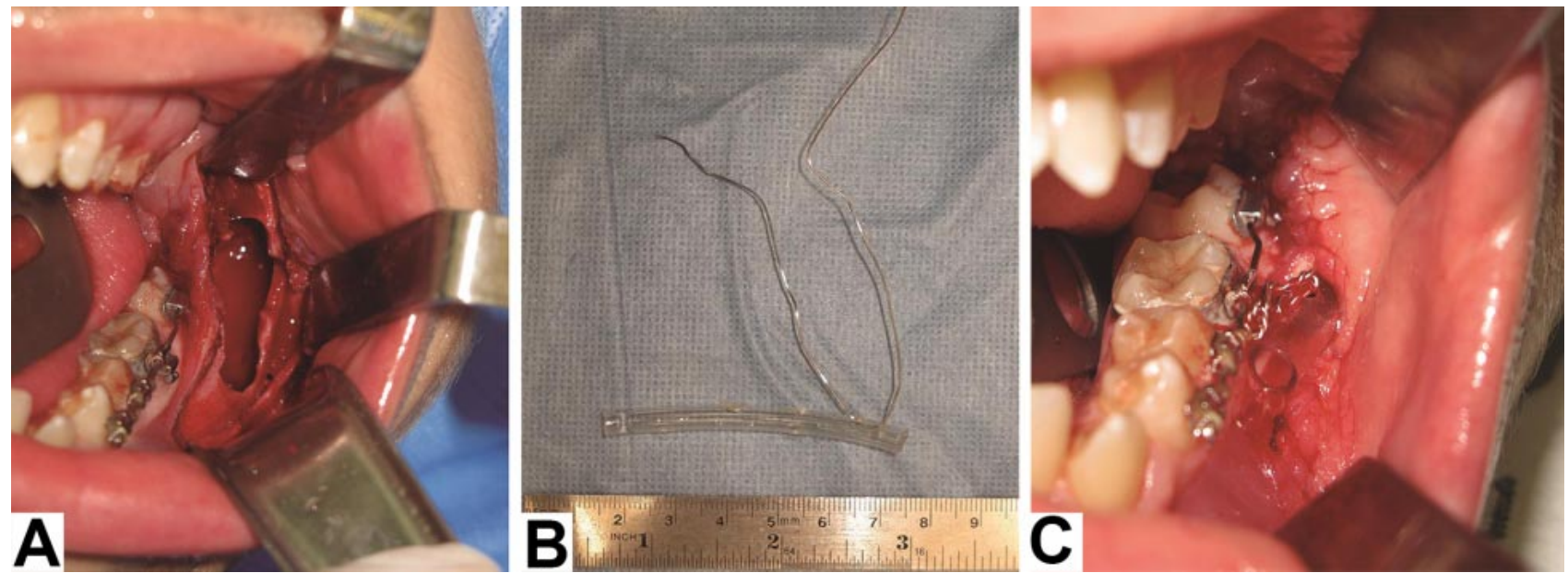

Fig. 2. A. Appearance of the cystic lesion site immediately after enucleation and curettage. B. The rigid drain, containing the infusion set tube and steel wire $n^{\circ} 1$. 2. C. View of the installed drain. 


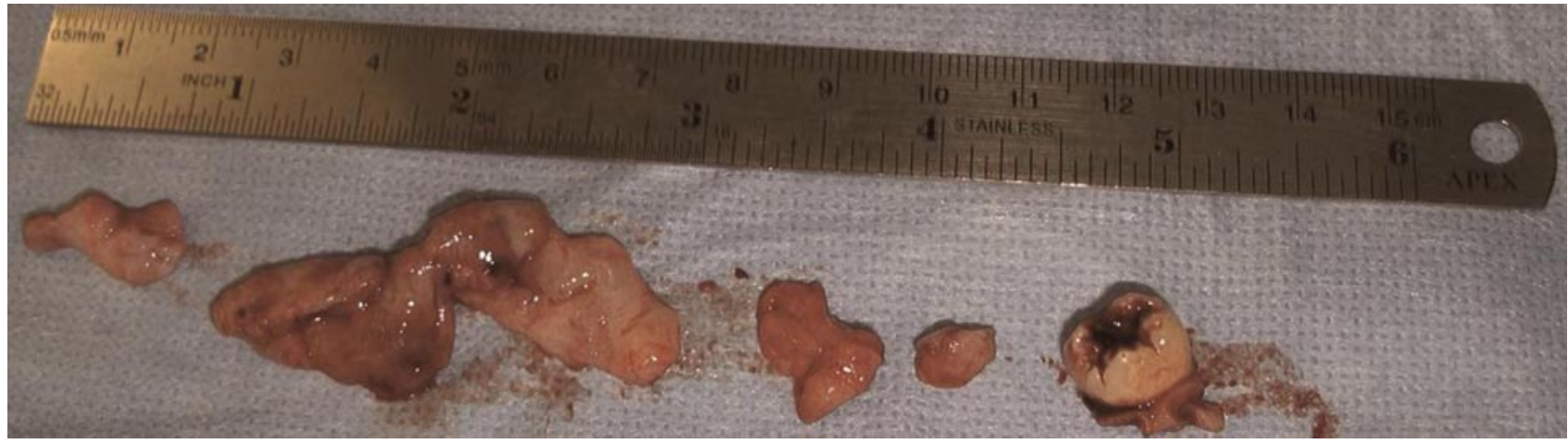

Fig. 3. Macroscopic specimen sent for histopathological analysis.

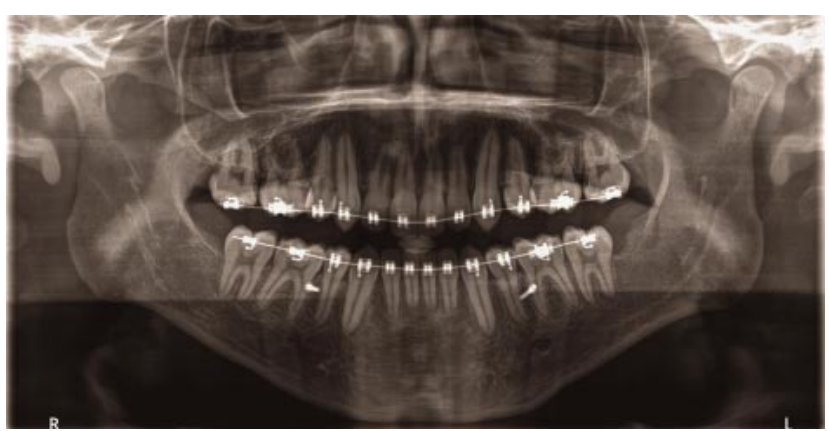

Fig. 4. Panoramic radiograph after eight years of follow-up. Note the new bone formation.

\section{DISCUSSION}

We reported a case of conservative treatment of odontogenic keratocyst with eight years follow-up. The discussion was based on the literature review of case reports on the topic. We applied the CARE guidelines, seeking outstanding achievement in the description of the case report (CARE - Case Report Guidelines, 2020). The authors observed the quality criteria established in the literature for case reports (Murad et al., 2018). We searched the literature in four databases: PubMed (101 articles), ScienceDirect (51 articles), LILACS (229 articles) and Web of Science (71 articles), totaling 452 articles. After eliminating duplicate articles, 253 articles remained. The descriptor combined with the Boolean operator "and" were: "Keratocyst" and "Odontogenic Cysts" and "Odontogenic tumor" and "Case reports". After exclusion from the title content, 200 article abstracts were selected, with 69 screened and 44 determined for eligibility assessment. Of these, only 27 met the inclusion criteria. The criteria for study eligibility included: 1 - Case report and case series of odontogenic keratocyst with at least one year of follow- up; 2 - Surgical treatment (excluding resection treatments); 3 - No language restriction; 4 - Without publication date restriction. Table I shows the demographic and clinical characteristics of 28 cases of keratocyst (multilocular, or unilocular) found in the literature, and the present report.

The literature review showed that the mandible was the most affected bone, covering about $71.4 \%$ of cases (Sombatpium \& Petersen, 1980; Webb \& Brockbank, 1984; Eyre \& Zakrzewska, 1985; Carr \& Green, 1988; Hyun et al., 2009; Ocaña et al., 2009; Rabelo et al.; 2010; Nishikawa et al., 2011; Contar et al.,2011; Deboni et al., 2012; Morais de Melo et al., 2012; Lacarbonara et al., 2014; De Molon et al., 2015; Zhang et al., 2016; Pittl et al., 2017). The ramus and angle was the most affected site, and the most frequent the radiological aspect was unilocular (Rao, 2015), which was present in $71.4 \%$ of the reviewed cases (Sombatpium \& Petersen; Eyre \& Zakrzewska; Carr \& Green; Hyun et al.; Ocaña et al.; Rabelo et al.; Rajkumar et al., 2011; Nishikawa et al.; Contar et al.; Deboni et al.; Morais de Melo et al.; Marcotullio et al. 2014; Lacarbonara et al., 2014; Sampieri et al., 2014; De Molon et al.; Nomura et al., 2015; Zhang et al.; Pittl et al.).

In most cases $(78.6 \%)$, the lesions were associated with dental units (Sombatpium \& Petersen; Eyre \& Zakrzewska; Carr \& Green; Hyun et al.; Ocaña et al.; Rajkumar et al.; Gupta et al., 2011; Nishikawa et al.; Deboni et al.; Roopak et al., 2014; Marcotullio et al., 2014; Lacarbonara et al.; Sampieri et al.; De Molon et al.; Nomura et al.; Zhang et al.; Pittl et al.), corroborating the case described. There was a predominance of males (Sombatpium \& Petersen; Eyre \& Zakrzewska; Hyun et al.; Ocaña et al.; Rabelo et al.; Nishikawa et al.; Contar et al.; Roopak et al.; Marcotullio et al.; De Molon et al.; Zhang et al.), representing $57.1 \%$, with the age group of adults 


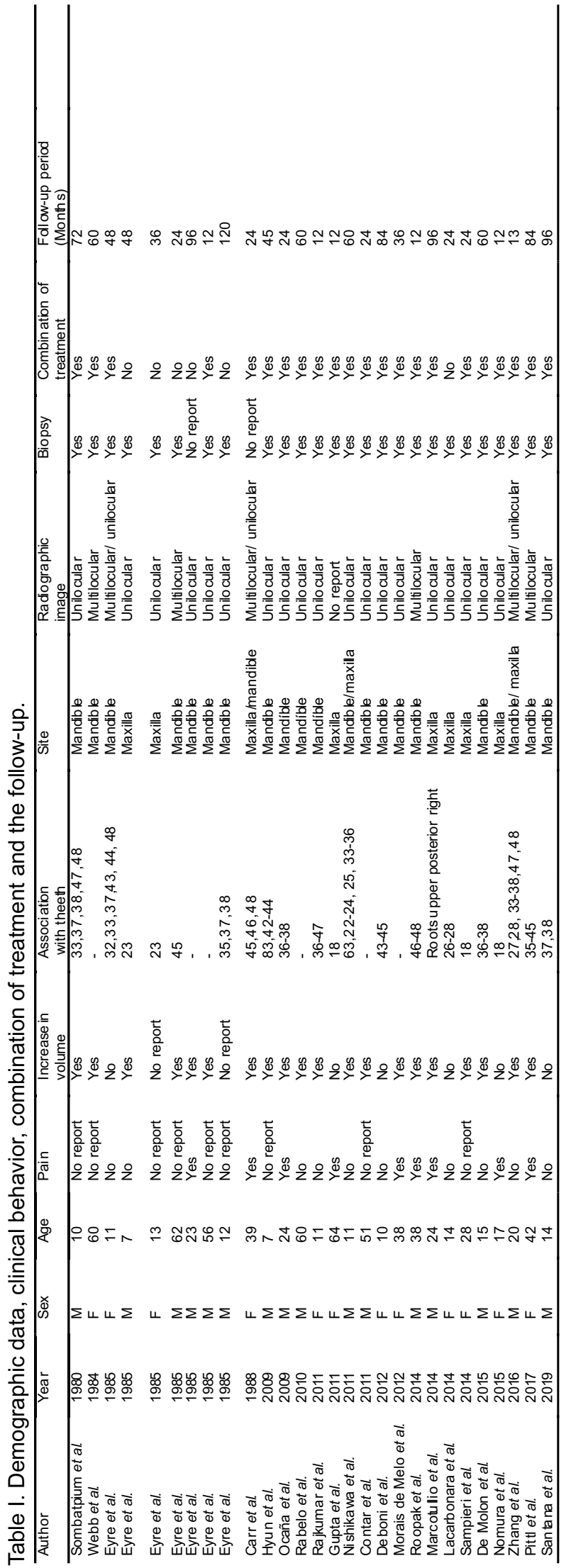

being the highest (mean of 28,1 118,3 years) (Webb \& Brockbank; Eyre \& Zakrzewska; Carr \& Green; Ocaña et al.; Rabelo et al.; Gupta et al.; Contar et al.; Morais de Melo et al.; Roopak et al.; Marcotullio et al.; Sampieri et al; Zhang et al.; Pittl et al.).

Increase in volume and pain are atypical findings in keratocyst, and most of the cases are asymptomatic (Srinivasan et al., 2018). Thus, early diagnosis occurs by chance, as reported in the present case referred by the patient's orthodontist. Increase in volume of the cyst occurred in $75 \%$ of reported cases (Sombatpium \& Petersen; Webb \& Brockbank; Eyre \& Zakrzewska; Carr \& Green; Hyun et al.; Ocaña et al.; Rabelo et al.; Rajkumar et al.; Nishikawa et al.; Contar et al.; Morais de Melo et al.; Roopak et al.; Marcotullio et al.; Sampieri et al.; De Molon et al.; Zhang et al.; Pittl et al.) and pain, in 39.3 \% (Eyre \& Zakrzewska; Carr \& Green; Ocaña et al.; Gupta et al.; Morais de Melo et al.; Roopak et al.; Marcotullio et al.; Nomura et al.; Pittl et al.). In most cases $(92.9 \%)$, incisional biopsy was performed (Sombatpium \& Petersen; Webb \& Brockbank; Eyre \& Zakrzewska; Hyun et al.; Ocaña et al.; Rabelo et al.; Rajkumar et al.; Gupta et al.; Nishikawa et al.; Contar et al.; Deboni et al.; Morais de Melo et al.; Roopak et al; Marcotullio et al.; Lacarbonara et al.; Sampieri et al.; De Molon et al.; Nomura et al.; Zhang et al.; Pittl et al.) including in the present report.

Our case report emphasized the effectiveness of the combined conservative surgical management (enucleation followed by delicate curettage) of the odontogenic keratocyst confirmed by the long followup period. Twenty-two of the twenty-seven cases of the literature review $(78.6 \%)$ were also conducted with conservative approach (Sombatpium \& Petersen; Webb \& Brockbank; Eyre \& Zakrzewska; Carr \& Green; Hyun et al.; Ocaña et al.; Rabelo et al.; Rajkumar et al.; Gupta et al.; Nishikawa et al.; Contar et al.; Deboni et al.; Morais de Melo et al; Roopak et al.; Marcotullio et al.; Sampieri et al.; De Molon et al.; Nomura et al.; Zhang et al.; Pittl et al.). Literature review evidenced a combination of procedures for odontogenic keratocyst treatment such as marsupialization and/or decompression, curettage and/or peripheral osteotomy, enucleation and/or the use of cryotherapy or other chemical solutions and tooth extraction (Sombatpium \& Petersen; Webb \& Brockbank; Eyre \& Zakrzewska; Carr \& Green; Hyun et al.; Ocaña et al.; Rabelo et al.; Rajkumar et al.; Gupta et al.; Nishikawa et al.; Contar et al.; Deboni et al.; Morais de Melo et al.; Roopak et al.; Marcotullio et al.; Sampieri et al.; De Molon et al.; Nomura et al.; Zhang et al.; Pittl et al.). 
Due to the high recurrence of odontogenic keratocyst, after conservative treatment, it is necessary to adopt complementary treatment, either by physical or chemical methods (Ribeiro Júnior et al., 2007) as a way to achieve treatment effectiveness. In our case, we conducted first the enucleation, followed by the soft tissue curettage and installation of a drain, removed after a period of one month. There are two possibilities for resolving these lesions with the use of marsupialization: 1- the squamous metaplasia of the epithelium 2replacement of the cystic epithelium to the normal epithelium (Pinto et al., 2015). In agreement with literature, we opted for drain irrigation of the cystic site to stimulate cellular metaplasia.

Different factors may influence the choice of the most appropriate treatment, including extension and location of the lesion, the aspect of lesion (unilocular or multilocular), presence of cortical perforation, soft tissue involvement, and age of the patient. Conservative surgical options have been previously described, and if risk of bone fracture exists, decompression and/or marsupialization is recommended (Carneiro et al., 2012; Dias et al., 2015), leading to the decrease in intraluminal pressure and consequent bone neoformation, making the lesion smaller. In the reported case, factors such as age, the location of the lesion and the risk of fracture during the operation, led to enucleation of lesion without vigorous curettage.

Most keratocyst recurrences can be diagnosed in the first two or three years of follow-up (Alstad \& Abtahi, 2017; Alchalabi et al., 2017), however, there are reports of recurrence in the period of five to seven years after treatment. For this reason, annual monitoring with imaging examinations during the first five years is indicated. After that period, examinations every two or three years should be performed (Borghesi et al.). During the preservation of the described case, no lesion recurrence was observed, and according to the imaging exams, the cystic site was healed with bone. In most of the reviewed cases, there was no report of recurrence (82.1\%) (Webb \& Brockbank; Eyre \& Zakrzewska; Carr \& Green; Ocaña et al.; Rabelo et al.; Rajkumar et al.; Gupta et al.; Nishikawa et al.; Contar et al.; Deboni et al.; Morais de Melo et al.; Roopak et al.; Marcotullio et al.; Lacarbonara et al.; Sampieri et al.; De Molon et al.; Nomura et al.).

In some studies, post-surgical follow-up was much lower than our reported case (Eyre \& Zakrzewska; Carr \& Green; Hyun et al.; Ocaña et al.; Rajkumar et al.; Gupta et al.; Contar et al.; Morais de Melo et al.; Roopak et al.;
Lacarbonara et al.; Sampieri et al.; Nomura et al.; Zhang et al.). Recurrence was detected in two cases with followup higher than the average of five years (Sobaptium et al.; Pittl et al.), a recommended time in the literature (Pitak-Arnnop et al.; Hadziabdic et al.). In the five cases of recurrence (Sobpatium et al.; Eyre \& Zakrzewska; Hyun et al.; Zhang et al.; Pittl et al.), four showed an increase in volume, were associated with dental units and mandible involvement (Sobpatium et al.; Hyun et al.; Zhang et al.; Pittl et al.). Two case also presented maxillary involvement (Eyre \& Zakrzewska; Zhang et al.). All described treatments in Table I were combined.

In conclusion, conservative treatment was adequate for the described case of odontogenic keratocyst, as evidenced by eight years of clinical and radiographic monitoring. Most of the studies reported in the literature did not show recurrence of lesion after use of conservative treatment. However, there is a need for a long-term follow-up, as it is not yet possible to define the moment that OKC would be considered as free from recurrences.

SANTANA, D. C. P.; GARCIA, J. J.2; KUSTERER, L. E. F. L.; SARDINHA, S. C. S. \& CAVALCANTE, W. C. Queatoquiste odontogénico: Seguimiento de ocho años después del tratamiento conservador. Int. J. Odontostomat., 15(2):520-525, 2021.

RESUMEN: El objetivo de este estudio fue describir el tratamiento quirúrgico conservador del queratoquiste odontogénico, obedeciendo las pautas de CARE (Case Report Guidelines). Los hallazgos clínicos y demográficos en la literatura se compararon basándose en una revisión desarrollada a través de los Criterios de calidad establecidos en la literatura para casos clínicos y series de casos, donde se consultaron cuatro bases de datos para la investigación en salud. La lesión encontrada en el paciente del presente estudio fue detectada en un examen radiográfico de rutina, sin manifestaciones clínicas siendo tratada quirúrgicamente con abordaje conservador. El tratamiento con enucleación, curetaje e instalación de drenaje se instituyó al mismo tiempo quirúrgico y, actualmente, no muestra signos de recurrencia de la enfermedad. De los 27 casos utilizados en la revisión, la lesión predominó en pacientes hombres adultos,con un seguimiento medio de $46,7 \pm 28,1$ después de la cirugía. Los principales hallazgos clínicos como asociación con dientes, localización, patrón radiográfico y lesión extensa, corroboran el patrón clásico de presentación de la enfermedad descrito en el caso reportado. En conclusión, el tratamiento conservador fue exitoso para el caso clínico descrito, durante un seguimiento de ocho años. La mayoría de los estudios revisados no mostraron recurrencias con el tratamiento quirúrgico conservador empleado, sin embargo, se aconseja realizar un seguimiento a largo plazo.

PALABRAS CLAVE: Queratoquiste; quistes odontogénicos; tumores odontogénicos; reporte de caso. 


\section{REFERENCES}

Alchalabi, N.J.; Merza, A. M. \& Issa, S. A. Using Carnoy's solution in treatment of keratocystic odontogenic tumor. Ann. Maxillofac Surg. 7(1):51-6, 2017.

Alstad, V. \& Abtahi, J. Surgical removal of keratocystic odontogenic tumours via a Le Fort I osteotomy approach: a retrospective study of the recurrence rate. Int. J. Oral Maxillofac. Surg., 46(4):434-9, 2017.

Borghesi, A.; Nardi, C.; Giannitto, C.; Tironi, A.; Maroldi, R.; Bartolomeo, F. \& Preda, L. Odontogenic keratocyst?: imaging features of a benign lesion with an aggressive behaviour. Insights Imaging, 9(2):883-97, 2018.

CARE - Case Report Guidelines, 2020. Available from: www.carestatment.org

Carneiro, A. G.; Cardoso, J. Á.; Silva, V. P.; Benigno, J.; Cancio, A. V. \& Farias, J. G. One year of decompression followed by enucleation for the treatment of a keratocystic odontogenic tumor: a case report. $R$. F. O., 17:212-7, 2012.

Carr, R. J. \& Green, D. M. Multiple odontogenic keratocysts in a patient with type II (MITIS) ehlers-danlos syndrome. Br. J. Oral Maxillofac. Surg., 26(3):205-14, 1988.

Contar, C. M. M.; Pompermayer, A.; Souza, P. H. C.; Propst, G. B.; Costa, M. B.; Chagas, P. R; Machado, M. A. N. \& De Carli, J. P. Keratocystic odontogenic tumor: case report. Odonto, 19(37):25-32, 2011.

De Molon, R.; Verzola, M.; Pires. L.; Mascarenhas, V.; da Silva, R.; Cirelli, J. \& Barbeiro, R. Five years follow-up of a keratocyst odontogenic tumor treated by marsupialization and enucleation: A case report and literature review. Contemp. Clin. Dent., 6(5):106, 2015.

Deboni, M. C. Z.; Brozoski, M. A.; Traina, A. A.; Acay, R. R. \& NaclérioHomem, M. G. Surgical management of dentigerous cyst and keratocystic odontogenic tumor in children: a conservative approach and 7-year follow-up. J. Appl. Oral Sci., 20(2):282-5, 2012.

Dias, G.; Coelho, P. V.; Ribeiro, M. C. \& Mourato, M. Keratocystic odontogenic tumor. A conservative surgical approach. Rev. Port. Estomatol. Med. Dent. Cir. Maxilofac., 56(3):195-203, 2015.

Eyre, J. \& Zakrzewska, J. M. The conservative management of large odontogenic keratocysts. Br. J. Oral Maxillofac. Surg., 23(3):195-203, 1985.

Gupta, A.; Rai, B.; Nair, M. A. \& Bhut, M. K. Keratocystic odontogenic tumor with impacted maxillary third molar involving the right maxillary antrum: An unusual case report. Indian J. Dent. Res., 22:157-60, 2011.

Hadziabdic, N.; Dzinovic, E.; Udovicic-Gagula, D.; Sulejmanagic. N.; Osmanovic, A.; Halilovic S. \& Kurtovic-Kozaric, A. Nonsyndromic examples of odontogenic keratocysts: presentation of interesting cases with a literature review. Case Rep. Dent., 1-12, 2019.

Hyun, H. K.; Hong, S. D. \& Kim, J. W. Recurrent keratocystic odontogenic tumor in the mandible: A case report and literature review. Oral Surg. Oral Med. Oral Pathol. Oral Radiol. Endod., 108(2):e7-e10, 2009.

Lacarbonara, M.; Marzo, G.; Lacarbonara, V.; Monaco, A. \& Capogreco. $M$. Presentation of a keratocystic odontogenic tumor with agenesis: a case report. J. Med. Case Rep., 8(1):126, 2014.

Marcotullio, D.; lannella, G.; Zelli, M.; Marinelli, C. \& Magliulo, G. Rare and massive odontogenic parakeratotic cyst treated by endoscopic sinus surgery: a case report. J. Med. Case Rep., 8(1):223, 2014.

Morais de Melo, W.; Pereira-Santos, D.; Sonoda, C. K. \& Hochuli-Vieira, E. Decompression for management of keratocystic odontogenic tumor in the mandible. J. Craniofac. Surg., 23(6):e639-40, 2012.

Murad, M. H.; Sultan, S.; Haffar, S. \& Barzerbachi, F. Methodological quality and synthesis of case series and case reports. B. M. J. Evid. Based Med., 23:60-3, 2018.

Nishikawa, M.; Yamamoto, G.; Keisuke, O.; Saito, S.; Inui, T.; Nishida, N.; Takahiro, Y. \& Yoshiyuki, O. Orthodontic Treatment of Deep Impacted Teeth in Multiple Keratocystic Odontogenic. Tumor J. Oral Maxillofac. Surg., 69(6):1691-3, 2011.
Nomura, K.; Arakawa, K.; Fujishima, F.; Yamazaki, Y.; Ozawa, D.; Nomura, Y. \& Katori, Y. Minimally Invasive Treatment for Hard Palate-Invading Maxillary Keratocystic Odontogenic Tumor. Tohoku J. Exp., 237(4):267-72, 2015.

Ocaña, R. P.; Alves, F. A.; Franchim, G. H.; Morando, F. S. \& Jorge, W. A Treatment of extensive keratocystic odontogenic tumor by decompression and surgical complementation with Carnoy's solution. Rev. Port. Estomatol. Med. Dent. Cir. Maxilofac., 50(2):87-92, 2009.

Pinto, G. N. S.; Figueira, J. Á.; Gonçales, E. S.; Sant'ana, E. \& Tolentino, E. S. Marsupialization as definitive treatment of odontogenic cysts: report of two cases. R. F. O., 20(3):361-6, 2015.

Pitak-Arnnop, P.; Chaine, A.; Oprean, N.; Dhanuthai K.; Bertrand, J. C. \& Bertolus, C. Management of odontogenic keratocysts of the jaws: A ten-year experience with 120 consecutive lesions. J. Craniomaxillofac. Surg., 38(5):358-64, 2010.

Pittl, T. L.; Meier, M.; Hakl, P. \& Sutter, W, Turhani, D. Long-term observation of a large keratocystic odontogenic tumour of the mandible treated by a single enucleation procedure: A case report and literature review. Int. J. Surg. Case Rep., 34:119-22, 2017.

Rabelo, G. D.; Henriques, J. C. G.; Macedo, J. H.; Silva, C. J.; Cardoso, S. V.; Loyola, A. M. \& Durighetto Junior, A. F. Keratocystic odontogenic tumor involving the maxillary sinus: case report. Arq. Int. Otorrinolaringol., 14(3):364-7, 2010.

Rajkumar, G. C.; Hemalatha, M.; Shashikala, R. \& Sonal, P. Massive keratocystic odontogenic tumor of mandible: A case report and review of literature. Indian J. Dent. Res., 22:181-81, 2011.

Rao, J. J. QRS for BDS 4th Year: Oral and Maxillofacial Surgery. Nueva Delhi, Elsevier, 2015.

Ribeiro Júnior, O.; Borba, A. M.; Alves, C. A. F. \& Guimarães Júnior, J. Complications of Carnoy's solution in the treatment of odontogenic tumors. R. G. O., 55(3):263-6, 2007.

Roopak, B.; Singh, M.; Shah, A. \& Patel, G. Keratocystic odontogenic tumor: Treatment modalities: Study of 3 cases. Niger. J. Clin. Pract., 17:378-83, 2014

Sampieri, M. B. S.; Gonçales, E. S.; Tieghi Neto, V.; Nogueira, A. S. Turatti. E.; Cavalcante, R. B. \& Maia Júnior, V. M. Keratocystic odontogenic tumor in the maxillary sinus: a rare occurrence. Braz. J. Otorhinolaryngol., 80(2):178-9, 2014.

Sombatpium, K. \& Petersen, J. K. Nevoid basal cell carcinoma syndrome: Conservative dental treatment. Int. J. Oral Surg., 9(5):404-7, 1980.

Speight, P.; Devilliers, P.; Li, T. J.; Odell, E. W. \& Wright, J. M. World Health Organization Classification Of Tumours. Lyon, IARC Press, 2017. pp.235-6.

Srinivasan, B.; Prabhakar, S.; Balakrishna R.; Priya, N. S.; Sudarshan \& Veena, G. C. Calcifying Odontogenic Keratocyst: An Encounter and Recollection. Ann. Clin. Case Rep., 3:1561, 2018.

Webb, D. J. \& Brockbank, J. Treatment of the odontogenic keratocyst by combined enucleation and cryosurgery. Int. J. Oral Surg., 13(6):503-10, 1984.

Zhang, Q.; Li, W.; Han, F.; Huang, X. \& Yang, X. Recurrent keratocystic odontogenic tumor after effective decompression. J. Craniofac. Surg., 27(5):e490-1, 2016.

Dirección para correspondiente:

Weber Ceo Cavalcante

Faculdade de Odontologia da UFBA, $8^{\circ}$ andar

Av. Araújo Pinho, $n^{\circ} 62$

Canela, Salvador, CEP: 41100-150

Bahia

BRASIL

E-mail: dr.weberceo@gmail.com 